\title{
NUTRITIONAL QUALITY OF COMMERCIAL SWINE DIETS AT EACH PRODUCTION PHASE
}

\author{
Marisa Senra Condé ${ }^{1}$, Sérgio de Miranda Pena ${ }^{1}$, Bruno Grossi Costa Homem ${ }^{2 *}$, Onofre Barroca de \\ Almeida Neto ${ }^{1}$, Carlos Magno da Rocha Júnior ${ }^{2}$, Gabriela Peluso Demartini ${ }^{1}$
}

\begin{abstract}
The knowledge of the chemical composition of the pig diets provides decision-making for the obtaining of the maximum production performance of the animals. Therefore, the nutritional quality of commercial swine diets in each production stage was evaluated. Six different commercial diets used in IF Southeast MG, Rio Pomba Campus (Federal Institute Southeast MG, Rio Pomba) were collected, the analyses of moisture, mineral matter, crude protein, total phosphorus and water activity were conducted. The chemical composition found was compared with the information reported on the label as well as the nutrient requirements for each phase of the pigs. Some irregularities were observed when comparing the actual composition with that reported on the label. The pre-starter diet presented a moisture value above what is described on the product label. Regarding crude protein, the starter and grower diets did not meet the minimum levels specified on the label. As for phosphorus, the pre-starter and starter diets did not meet the levels shown on the labels. Regarding the crude protein requirements, the pre-starter diet presented value below and pregnancy and finisher diets showed values far above that required by pigs in these phases. For the water activity, no diet posed risk to fungal growth.
\end{abstract}

Keywords: comparison, labels, requirements, swine production.

\section{QUALIDADE NUTRICIONAL DE RAÇÕES COMERCIAIS PARA SUÍNOS EM CADA FASE DE PRODUÇÃO}

\begin{abstract}
RESUMO - O conhecimento da composição químico-bromatológica das rações de suínos proporciona tomada de decisões para a obtenção do máximo desempenho produtivo dos animais. Diante disso, avaliou-se a qualidade nutricional das rações comerciais para suínos em cada fase de criação. Foram coletadas seis diferentes rações comerciais utilizadas no IF Sudeste MG, Campus Rio Pomba, sendo realizadas as análises de umidade, matéria mineral, proteína bruta, fósforo total e atividade de água. A composição químico-bromatológica encontrada foi comparada com as informações descritas no rótulo, bem como com as exigências nutricionais para cada fase dos suínos. Foram observadas algumas irregularidades quando se comparou a composição real com a descrita no rótulo. A ração pré-inicial apresentou valor de umidade acima do que é descrito no rótulo do produto. Em relação à proteína bruta, as rações inicial e crescimento não atenderam aos níveis mínimos especificados na embalagem. Já para o fósforo, as rações pré-inicial e inicial não atenderam aos níveis apresentados nos rótulos. Em relação às exigências de proteína bruta, a ração pré-inicial apresentou valor abaixo e as rações de gestação e Terminação apresentaram valores muito acima do exigido por suínos nestas fases. Para a atividade de água, nenhuma ração apresentou risco para crescimento fúngico.
\end{abstract}

Palavras chave: comparação, exigências, rótulos, suinocultura.

\footnotetext{
${ }^{1}$ Departamento de Zootecnia, Instituto Federal de Educação, Ciência e Tecnologia do Sudeste de Minas Gerais, Campus Rio Pomba, Rio Pomba, 36180-000, MG, Brazil.

${ }^{2}$ Departamento de Zootecnia, Universidade Federal de Lavras, Lavras, 37200-000, MG, Brazil.

* Corresponding author: B.G.C. Homem, zoogrossi@gmail.com
} 


\section{INTRODUCTION}

The knowledge of the chemical composition of pig diets can provide the grower decision-making for the obtaining of the maximum production performance of animals, mainly to find fraud and lack of adjustments of the nutritional levels established on the levels of the packages to meet the nutritional levels established adjustments on the labels of commercial feeds.

The quality has been the objective in all the branches of the industry. If, on the one hand, this factor is responsible for the search of the continuous improvement, on the other hand, it ensures the survival in the competitiveness among markets. The quality of a product, defined as its suitability for the use to which it is intended, can be warranted by lots of measures, which abridge in the application of safe technologies to raw materials of good quality. The monitoring of the characteristics of products and processes can be implemented by means of many analytical tools, among which the physic-chemical methods stand out as both fast and straight (Bertolino, 2010).

The quality of the raw materials and feeds intended for animal feeding has reached quality levels comparable to the standards of products intended for human consumption. Due to the intensification of farming activity, the feeds given to the livestock food should be nutritionally balanced as well as the health guarantees for their supply and marketing (Gabbi et al., 2011).

By standardization of the Ministry of Agriculture, it is mandatory to be reported on the product labels the warranty levels in terms of chemical composition. Many times, the warranty level contained on the labels are not sufficient to ensure that the product provides good use of nutritional principles and maximal expression of their production potential, since failures can occur or even misstatements causing no effective evaluation of the feeds to there to be (Gabbi et al., 2011).

Therefore, it is important to conduct experimental tests which assess both chemically and biologically the commercial diets, because the results obtained would alert the manufacturers about the control of quality of the products and constitute in guidance to technicians and farmers, avoiding possible defaults in the formulations, which would harm the obtaining of good performance indexes (Machado et al., 2012).

In this context, the present study was conducted with the aim of measuring the chemical composition of commercial swine diets in various production stages.

\section{MATERIALS AND METHODS}

For measuring of the chemical composition, six commercial diets were utilized, namely, one from each respective phase of swine production (lactation, pregnancy, pre-starter, starter, grower and finisher), where they were respectively named as $\mathrm{LD}, \mathrm{PD}, \mathrm{PSD}, \mathrm{SD}, \mathrm{GD}$ and FD.

For the undertaking of the measurement, the diets given to the Swine Production Sector of the Animal Science Department of IF Southeast MG, Campus Rio Pomba were utilized. The sampling was conducted in sealed containers of feeds and within the shelf life, using a sampler for the taking of samples at different points in the bag.

Afterwards, the feeds were ground in an analytical mill and transferred to pots identified. For chemical analyses, the methodologies proposed by Silva and Queiroz (2002) were utilized for feeds and ingredients, the analyses being conducted in the laboratory of Food Analysis of the Food Science and Technology Department and Animal Nutrition Laboratory of the Animal Science Department of IF Southeast MG, Rio Pomba (Federal Institute Southeast MG, Rio Pomba). The analyses carried out were: moisture (M), mineral matter (MM), phosphorus $(\mathrm{P})$, crude protein $(\mathrm{CP})$. The water activity (Wa) analysis was conducted by the methodology of the dew point principle (AOAC, 2005) using an Aqualab equipment (Decagon Inc., USA.).

The experiment was a completely randomized design with five replicates per diet of each phase. The data obtained were compared with the values proposed on the label as well as the nutrient requirements proposed by Rostagno et al. (2011). The means of the analyses of the feeds were subjected to the descriptive analysis using the SISVAR 5.3 program (Ferreira, 2011).

\section{RESULTS AND DISCUSSION}

The results of the chemical analysis of the diets of different swine production phases are shown in Tables 1 and 2.The warranty levels given by the manufacturers of the diets are presented in Table 3 and the nutrient requirements of pigs at different phases are in Table 4.

The labels of the containers presented the data of basic nutritional composition including moisture, crude protein, ether extract, fibrous matter, mineral matter, calcium and phosphorus, as required by Brazilian legislation (Brasil, 2009). 
Table 1 - Chemical analysis of swine feeds of different commercial categories

\begin{tabular}{|c|c|c|c|}
\hline \multirow{2}{*}{ Itens } & \multicolumn{3}{|c|}{ Feeds } \\
\hline & $\mathrm{LD}^{3}$ & $\mathrm{PD}^{4}$ & $\mathrm{PSD}^{5}$ \\
\hline \multicolumn{4}{|c|}{ Moisture (\%) } \\
\hline Mean (min-max) & $12.91(12.83-13.01)$ & $12.92(12.51-13.23)$ & $13.60(13.34-13.79)$ \\
\hline SEM $^{1}$ & 0.06 & 0.22 & 0.13 \\
\hline $\mathrm{CV}^{2}$ & 0.75 & 2.90 & 1.70 \\
\hline \multicolumn{4}{|c|}{ Crude protein $(\%)$} \\
\hline Mean (min-max) & $21.13(21.98-20.59)$ & $15.21(15.10-15.33)$ & $19.00(17.65-20.12)$ \\
\hline SEM & 0.43 & 0.07 & 0.72 \\
\hline $\mathrm{CV}$ & 3.53 & 0.76 & 6.59 \\
\hline \multicolumn{4}{|c|}{ Mineral matter $(\%)$} \\
\hline Mean (min-max) & $5.98(5.64-6.17)$ & $9.14(9.00-9.25)$ & $10.87(10.60-11.36)$ \\
\hline SEM & 0.17 & 0.07 & 0.25 \\
\hline $\mathrm{CV}$ & 5.01 & 1.42 & 3.96 \\
\hline \multicolumn{4}{|c|}{ Total phosphorus $(\%)$} \\
\hline Mean (min-max) & $0.60(0.56-0.62)$ & $0.54(0.52-0.56)$ & $0.55(0.53-0.57)$ \\
\hline SEM & 0.02 & 0.01 & 0.01 \\
\hline $\mathrm{CV}$ & 5.50 & 4.44 & 3.63 \\
\hline \multicolumn{4}{|c|}{ Water activity (\%) } \\
\hline Mean (min-max) & $0.708(0.708-0.708)$ & $0.708(0.707-0.709)$ & $0.707(0.706-0.707)$ \\
\hline SEM & 0.0 & 0.0006 & 0.0003 \\
\hline $\mathrm{CV}$ & 0.0 & 0.16 & 0.08 \\
\hline
\end{tabular}

${ }^{1} \mathrm{SE}$ : Standard Error of the Mean; ${ }^{2} \mathrm{CV}$ : Coefficient of Variation, ${ }^{3} \mathrm{LD}$ : Swine diets in the lactation phase; ${ }^{4} \mathrm{PD}$ : Swine diet in the pregnancy phase; ${ }^{5} \mathrm{PSD}$ : Swine diet in the pre-starter phase.

Table 2 - Chemical analysis of swine diets of different commercial categories

\begin{tabular}{|c|c|c|c|}
\hline \multirow{2}{*}{ Itens } & \multicolumn{3}{|c|}{ Feeds } \\
\hline & $\mathrm{SD}^{3}$ & $\mathrm{GD}^{4}$ & $\mathrm{FD}^{5}$ \\
\hline \multicolumn{4}{|c|}{ Moisture (\%) } \\
\hline Mean (min-max) & $12.52(12.29-12.98)$ & $12.93(12.82-13.14)$ & $12.84(12.43-13.09)$ \\
\hline SEM1 & 0.23 & 0.10 & 0.21 \\
\hline $\mathrm{CV} 2$ & 3.13 & 1.42 & 2.80 \\
\hline \multicolumn{4}{|c|}{ Crude protein $(\%)$} \\
\hline Mean (min-max) & $19.29(18.98-19.53)$ & $17.86(17.51-18.46)$ & $16.94(16.90-16.99)$ \\
\hline SEM & 0.16 & 0.30 & 0.03 \\
\hline $\mathrm{CV}$ & 1.44 & 2.93 & 0.27 \\
\hline \multicolumn{4}{|c|}{ Mineral matter $(\%)$} \\
\hline Mean (min-max) & $5.49(5.31-5.62)$ & $4.28(4.20-4.33)$ & $4.96(4.80-5.12)$ \\
\hline SEM & 0.09 & 0.04 & 0.09 \\
\hline $\mathrm{CV}$ & 2.89 & 1.68 & 3.17 \\
\hline \multicolumn{4}{|c|}{ Total phosphorus $(\%)$} \\
\hline Mean (min-max) & $0.38(0.37-0.41)$ & $0.41(0.37-0.45)$ & $0.38(0.37-0.39)$ \\
\hline SEM & 0.01 & 0.02 & 0.01 \\
\hline $\mathrm{CV}$ & 5.56 & 10.24 & 4.04 \\
\hline \multicolumn{4}{|c|}{ Water activity $(\%)$} \\
\hline Mean $(\min -\max )$ & $0.686(0.685-0.686)$ & $0.702(0.7-0.704)$ & $0.694(0.693-0.695)$ \\
\hline SEM & 0.0003 & 0.001 & 0.0005 \\
\hline $\mathrm{CV}$ & 0.08 & 0.27 & 0.14 \\
\hline
\end{tabular}

${ }^{1} \mathrm{SE}$ : Standard Error of the Mean; ${ }^{2} \mathrm{CV}$ : Coefficient of Variation; ${ }^{3} \mathrm{SD}$ : Swine diet in the starter phase; ${ }^{4} \mathrm{GD}$ : Swine diet in the grower phase; ${ }^{5} \mathrm{FD}$ : Swine diet in the finishing phase. 
Table 3 - Warranty levels of commercial swine diets in the different phases

\begin{tabular}{|c|c|c|c|c|c|c|}
\hline \multirow{3}{*}{ Parameter } & \multicolumn{6}{|c|}{ Warranty levels presented on the labels } \\
\hline & \multicolumn{6}{|c|}{ Diets evaluated } \\
\hline & LD & PD & PSD & SD & GD & FD \\
\hline $\mathbf{M}^{1}$ (Maximum) & 13 & 13 & 13 & 13 & 13 & 13 \\
\hline $\mathrm{CP}^{2}$ (Minimum) & 20 & 14.5 & 19 & 20 & 18 & 16.5 \\
\hline $\mathrm{P}^{3}$ (Minimum) & 0.5 & 0.5 & 0.6 & 0.47 & 0.39 & 0.35 \\
\hline
\end{tabular}

${ }^{1}$ Moisture in $\% ;{ }^{2}$ Crude Protein in $\% ;{ }^{3}$ Total Phosphorus in $\%$.

Table 4 - Nutrient requirements of swine of high genetic potential of average performance in the different phases

\begin{tabular}{|c|c|c|c|c|c|c|}
\hline \multirow{3}{*}{ Parameter } & \multicolumn{6}{|c|}{ Swine requirements of high performance ${ }^{1}$} \\
\hline & \multicolumn{6}{|c|}{ Diets evaluated } \\
\hline & LD & $\mathrm{PD}$ & PSD & $\mathrm{SD}$ & GD & FD \\
\hline $\mathrm{CP}(\%)$ & 20.18 & 12.45 & 20.30 & 18.31 & 16.56 & 13.74 \\
\hline $\mathrm{P} 2(\%)$ & 0.41 & 0.38 & 0.50 & 0.37 & 0.29 & 0.23 \\
\hline
\end{tabular}

${ }^{1}$ Source: $(30) ;{ }^{2}$ Total Phosphorus in $\%$.

It is realized now that the moisture levels discriminated in the warranty levels are in accordance with the feeds LD, PD, SD, GD and FD. Only the feed PSD presented moisture value above that stated on the label.

This value of moisture found above that reported on the label may be associated with different factors such as ingredients with a high moisture content, inadequate transportation conditions and storage of the product in moist places, both in the factory and on the farm. The cares both in the transportation and storage place besides influencing the moisture content of raw materials and feeds also affect the microbiological quality of them (Kan and Meijer, 2007; Sone, 2001; Tanaka et al., 2001).

According to Santin et al. (2004), about $30 \%$ of the losses in raw materials destined for animal feeding are caused by the lack of structure in terms of transportation, the non-ideal conditions of storage and distribution of ready diets.

This finding corroborates with the ones by Point et al. (2001) who pointed out that the storage areas with good ventilation and gas exhaustion systems and with room temperature control are capable of avoiding changes in the moisture of the feeds destined to animal feeding.

In addition, Genkawa et al. (2008) state that the package characteristics and relative air humidity in the storage room influence in the moisture exchange in the environment where the paper packages are more likely to favor the absorption or loss of moisture in the raw material in the sense of balancing the environment.

However, in relation to the levels of $\mathrm{CP}$, both the diets SD and GD did not meet the minimum levels specified on the package, values a little below the values described on the labels being found. Regarding the requirements of animals, only the PSD presented values below that recommended by Rostagno et al. (2011) for this particular production phase. However, for diets of pregnancy and termination the values found much higher so that the requirements proposed by Rostagno et al. (2011).

The furnishing of this nutritive principle in adequate quantities is essential to the maximization of the animals' performance (Machado et al., 2012).

Amino acids (and generally proteins) are required by a number of biological processes, including growth, formation and repair of blood tissues and synthesis of immune system proteins. The lack of crude protein in the diet and therefore lack of essential amino acids is compensated for via the tissues catabolism, resulting into lower growth rates, lethargy, decreased immune system functioning and decreased milk production in lactating animals (Dzanis, 1997).

However, the GD and FD presented values of CP much higher than those required by the pigs in these respective phases (Rostagno et al., 2011). Excess amino 
acids in the swine diet implies in metabolic steps involving the removal of nitrogen via feces and urine (Gasparotto et al., 2001; Kerr et al., 2003). In this process, there is expenditure of energy, reflecting negatively on the production cost, in addition to the increased polluting power of these animals' wastes (Trindade Neto et al., 2009).

Currently, a new conception in the feeding strategy with protein sources has been addressed in relation to the coming of the environmental problems related to the pollution of nitrogen $(\mathrm{N})$ and ammonia $\left(\mathrm{NH}_{3}\right)$ from animal manure. Today, nutritionists aim to adjust the requirements of pigs to maximize production performance as far as the avoidance of the excess protein and amino acids is concerned. This problem is not related only to the $\mathrm{N}$ retained in production but also in terms of the fraction of unused $\mathrm{N}$ of the ingested $\mathrm{N}$ (Moreira et al., 2002).

Therefore, the perfect management of protein feeding according to the needs of the pig is to close the protein/amino acid adjustment to meet the requirement and obtain a low level of production of nitrogen and $\mathrm{NH}_{3}$, this process being called the ideal protein. The ideal protein concept has been increasingly advocated in swine nutrition, since it is related to better utilization of nutrients (Kerr et al., 2003; Oliveira et al., 2006). In addition, the adequate dietary supplementation with synthetic amino acids is directly linked to the deposition of muscle tissue, improving both the performance and carcass characteristics (Oliveira et al., 2003). Also, it is proposed that all the amino acids may be related to lysine and if the requirement of this amino acid varies either due to the genotype or body weight, the pattern of other amino acids alters proportionally, maintaining a constant ratio with this reference amino acid (Firman and Boling, 1998).

As to the contents of $\mathrm{P}$, it can be found that the diets PSD and SD did not meet the proposed levels on the labels. While, all the diets satisfactorily met the levels of requirements for swine proposed by Rostagno et al. (2011).

Of the minerals supplemented in swine diets, phosphorus has required special attention because, in addition to performing many functions in the body, the deposition of muscle tissue requires energy in the form of ATP. Quantitatively, the most important function of phosphorus is the formation and mineralization of the organic matrix of the bone. However, the phosphorus also acts as a component of nucleic acids (DNA and
RNA) that are essential for cell growth and differentiation, and together with other elements, participate in the maintenance of osmotic pressure and acid -base balance. As a component of phospholipids, it contributes to the fluidity and integrity of the cell membrane (Saraiva et al., 2012). Besides bone abnormalities, phosphorus deficiency can cause low feed intake, reduced feed efficiency, reproductive disorders and appetite alterations (Underwood and Suttle, 1998).

The diets did not present on their labels the content of mineral matter found in them, yet they presented on the labels the concentrations of all the minerals present.

A relevant fact is that piglets require large amounts of minerals due to the rapid growth in which they lie, for the development of bones, tissues, which can be confirmed by the high concentration of mineral matter in the RPI. Thus, the balancing and supply of adequate amounts of minerals is of extreme importance for exerting vital functions in our organism.

Excess minerals can cause several harms to the animal, usually being ascribed to the protein sources used in the feed manufacture, especially those of animal origin. One of the criteria for the evaluation of the protein ingredients of animal origin is their protein: mineral matter ratio (Cowell et al., 2000). The more mineral matter represented by the largest share of bones in the composition of the ingredient, usually lower its digestibility. Apart from that aspect, protein meals with excess minerals present limitations of inclusion in the formula because they possess great amounts of calcium, phosphorus and magnesium (Carciofi et al., 2009).

As an example, two protein ingredients used in the manufacture of feeds for monogastric animals are quoted: meat and bone meal with $45 \%$ crude protein, $11.3 \% \mathrm{Ca}$ and $5.9 \% \mathrm{P}$ and poultry viscera flour with $58 \%$ $\mathrm{CP}, 4.4 \% \mathrm{Ca}$ and $2.6 \% \mathrm{P}$ (Rostagno et al., 2011). To add $10 \%$ of protein to the diet by means of meat and bone meal, around $2.5 \%$ of Ca should be added whereas with poultry viscera meal only $0.8 \%$ (Carciofi et al., 2006).

For water activity (Wa), it is found that the maximum value allowed of it was not contained on the label, due to the non-enforcement of this parameter being stated on the labeling of feeds (Brasil, 2009). With the results, it is found that the values of Wa of the different diets were not included in the minimum limits of fungal growth and aflatoxin production, which are respectively 0.780 and 0.860 (Gabbi et al., 2011). 
The analysis of Wa provides values that allow greater control of microorganisms in the raw material and industrialized products of animal origin, especially the agents that assume importance in terms of public health such as Clostridium botulinum, Staphylococcus aureus, Salmonella sp., toxigenic fungi, among others (Gabbi et al., 2011).

One of the queries that influences the quality of raw materials and feeds is the microbiological profile of them, dependent on factors such as temperature, humidity, water activity, levels of oxygen and of available nutrients (Magan and Aldred, 2007; Pacin et al., 2009; Nanguy et al., 2010). According to Bessa et al. (2004) and Carney et al. (2006), various raw materials used in the production of feeds for animal feeding are contaminated with microorganisms such as Salmonella and Escherichia coli, which has caused economic losses and reduction in the quality of the feeds offered to livestock. The amplitude of the cereals offered on the Brazilian market contaminated by molds and yeasts varies between 25-70 \% (Silva et al., 2000), in which the handling of the feed should be associated with that and other features of the evaluated product (Citadin et al., 2009).

The alternatives which feed factories possess either to control or minimize this problem is to make use of additives such as antifungal agents (Pont et al., 2001; Lind et al., 2005) as well as to control some physicochemical parameters of these raw materials and feeds, as for instance moisture (Gock et al., 2003; Olstorpe et al., 2010) and water activity (Rosso and Robinson, 2001).

\section{CONCLUSIONS}

Only the pre-starter diets presented moisture value above that reported on the product label. However, regarding the crude protein, the starter and grower diets did not meet the minimum levels specified on the package.

The pre-starter diets presented crude protein values below that required by the pigs at this phase. However, both pregnancy and finisher diets showed values of crude protein much higher than those required by pigs in the respective phases.

The pre-starter and starter diets did not meet the levels of phosphorus proposed on the labels. However, all the diets satisfactorily met the levels of phosphorus requirements for pigs.
For the water activity values, the different diets showed did not risk of fungal growth.

\section{ACKNOWLEDGEMENTS}

To Federal Institute Southeast MG, Rio Pomba for the opportunity of carrying out the project and to CNPQ for the grant of the scholarship.

\section{REFERENCES}

AOAC. Association Official Method of Analisys of AOAC internacional. Thiex, NJW (E.d.) Animal feed. Art 965-16. Sampling of animal feed and food. Art. 930.15. 18 ed. Maryland: AOAC international 2005.

\section{BERTOLINO, M.T. Gerenciamento da qualidade na indústria alimentícia. Porto Alegre: Artmed, 2010.}

BESSA, M.C.; COSTA, M.; CARDOSO, M. Prevalência de Salmonella sp. em suínos abatidos em frigoríficos do Rio Grande do Sul. Pesquisa Veterinária Brasileira, v.24, n.2, p.80-84, 2004.

BRASIL. Ministério da Agricultura, Pecuária e Abastecimento. Instrução Normativa $\mathrm{N}^{\circ}$ 30, de 05 de agosto de 2009. Estabelece critérios e procedimentos para o registro de produtos, para rotulagem e propaganda e para isenção da obrigatoriedade de registro de produtos destinados à alimentação de animais de companhia. Diário Oficial [da República Federativa do Brasil], Brasília, 07 de agosto de 2009.

CARCIOFI, A.C.; VASCONCELLOS, R.S.; BORGES, N.C.; MORO, J.V.; PRADA, F.; FRAGA, V.O. Composição nutricional e avaliação de rótulo de rações secas para cães comercializadas em Jaboticabal-SP. Arquivo Brasileiro de Medicina Veterinária e Zootecnia, v.58, n.03, p.421-426, 2006.

CARCIOFI, A.C; TESHIMA, E.; BAZOLLI, R.S.; BRUNETTO, M.A.; VASCONCELLOS, R.S.; PEREIRA, G.T.; OLIVEIRA, L.D. Qualidade e digestibilidade de alimentos comerciais de diferentes segmentos de mercado para cães adultos. Revista Brasileira Saúde e Produção Animal, v.10, n.2, p.489-500, 2009. 
CARNEY, E.; O`BRIEN, S.B; SHERIDEN, J.J.; MC DOWELL, D.A; BLAIR, I.S.; DUFFY, G. Prevalence and level of Escherichia coli O157 on beef trimmings, carcasses and boned head meat at a beef slaughter plant. Food Microbiology, v.23, n.1, p.52-59, 2006.

CITADIN, A.S.; POZZA. M.S.S.; POZZA, P.C.; NUNES, R.V.; BORSATTI, L.; MANGONI, J. Qualidade do leite cru refrigerado e fatores associados. Revista Brasileira de Saúde e Produção Animal, v.10, n.1, p.52-59, 2009.

COWELL, C.S.; STOUT, N.P.; BRINKMANN, M.F. et al. Making commercial pet foods. In: HAND, M.S.; THATCHER, C.D.; REMILLARD, R.L. et al. (Eds.). Small animal clinical nutrition. 4.ed. Kansas: Mark Morris Institute, 2000, p.127-146.

DZANIS, D. Disorders of nutritional deficiency. In: MORGAN, R. (Ed.). Handbook of small animal practice. 3.ed. Philadelphia: Saunders, 1997, p.1227-1236.

FERREIRA, D.F. Sisvar: A computer statistical analysis system. Ciência e Agrotecnologia, v.35, p.1039-1042, 2011.

FIRMAN, J. D.; BOLING, D. Ideal protein in turkeys. Poultry Science, v.77, n.1, p.105-110, 1998.

GABBI, A.M.; CYPRIANO, L.; PICCININ, I. Aspectos microbiológicos e físico-químicos de três rações comerciais sob diferentes condições de armazenamento. Revista Brasileira Saúde e Produção Animal, v.12, n.3, p.784-793, 2011.

GENKAWA, T.; UCHINO, T.; MIYAMOTO, S.; INOUE, A.; IDE, Y.; TANAKA, F.; HAMANAKA, D. Development of mathematical model for simulating moisture content during the re-wetting of brown rice stored in film packaging.

Biosystems Engineering, v.101, n.4, p.445$451,2008$.

GASPAROTTO, L.; MOREIRA, I.; FURLAN, A.C.; MARTINS, E.N.; MARCOS JUNIOR, M. Exigência de lisina, com base no conceito de proteína ideal, para suínos machos castrados de dois grupos genéticos, na fase de crescimento. Revista Brasileira de Zootecnia, v.30, n.6, p.17421749, 2001.
GOCK, M.A.; HOCKING, A.D.; PITT, J.J.; POULOS, P.G. Influence of temperature, water activity and $\mathrm{pH}$ on growth of some xerophilic fungi. International Journal of Food Microbiology, v.81, n.1, p.11-19, 2003.

KAN, C.A.; MEIJER, G.A.L. The risk of contamination of food with toxic substances present in animal feed. Animal Feed

Science and Technology, v.133, n.1-2, p.84108, 2007.

KERR, B.J.; YEN, J.T.; NIENABER, J.A.; EASTER, R.A. Influences of dietary protein level, amino acid supplementation and environmental temperature on performance, body composition, organ weights and total heat production of growing pigs. Journal of Animal Science, v.81, n.8, p.1998-2007, 2003.

LIND, H.; JONSSON, H.; SCNHÜRER, J. Antifungal effect of dairy propionic bacteria: contribution of organic acids. International Journal of Food Microbiology, v.98, n.2, p.157-165, 2005.

MACHADO, L.C.; PINTO, E.R.A.; PINTO, L.O.R.; GERALDO, A.; SANTOS, T.A. MARTINS, M.G. Qualidade de rações comerciais para coelhos em crescimento. Revista Brasileira de Cunicultura, v.2, n.1, 2012.

MAGAN, N.; ALDRED, D. Postharvest control strategies: Minimizing mycotoxins in the food chain. International Journal of Food Microbiology, v.119, p.131-139, 2007.

MOREIRA, I.; GASPAROTTO, L.F.; FURLAN, A.C.; PATRÍCIO, V.M.I.; OLIVEIRA, G.C. Exigência de lisina para machos castrados de dois grupos genéticos de suínos na fase de terminação, com base no conceito de proteína ideal. Revista Brasileira de Zootecnia, v.31, n.1, p.96-103, 2002.

NANGUY, S.P.M.; CORNET, J.M.P.; BENSOUSSAN, M.; DANTIGNY, P. Impact of water activity of diverse media on spore germination of Aspergillus and Penicillium species. International Journal of Food Microbiology, v.142, n.1-2, p.273-276, 2010. 
OLIVEIRA, A.L.S.; DONZELE, J.L.; OLIVEIRA, R.F.M.; FERREIRA, A.S.; MOITA, A.M.S.; GENEROSO, R.A.R. Lisina em rações para suínos machos castrados selecionados para deposição de carne magra na carcaça dos 110 aos $125 \mathrm{~kg}$.

Revista Brasileira de Zootecnia, v.32, n.1, p.150-155, 2003.

OLIVEIRA, A.L.S.; DONZELE, J.L.; OLIVEIRA, R.F.M.; ABREU, M.L.T.; FERREIRA, A.S.; SILVA, F.C.O.; HAESE, D. Exigência de lisina digestível para suínos machos castrados de alto potencial genético para deposição de carne magra na carcaça dos 15 aos $30 \mathrm{~kg}$. Revista Brasileira de Zootecnia, v. 35, n. 6, p. 2338-2343, 2006.

OLSTORPE, M.; SCHNÜRER, J.; PASSOTH, V. Microbial changes during storage of moist crimped cereal barley grain under Swedish farm conditions. Animal Feed Science and Technology, v.156, n.1-2, p.37-46, 2010.

PACIN, A.M.; BOVIER, E.C.; GONZÁLEZ, H.H.L.; WHITECHURCH, E.M.; MARTÍNEZ, E.J.; RESNIK, S.L. Fungal and fumonisins contamination in Argentine maize (Zea mays L.) silo bags.

Journal of Agricultural and Food Chemistry, v.57, p.2778-2781, 2009.

PONT, G.; JORDANA, J.A.; CAMPANERA, J.M.; ARROYO, T.R. El problema de la contaminación fúngica en la industria de piensos. Barcelona: Lucta, 2001. 119p.

ROSSO, L.; ROBINSON, T.P. A cardinal model to describe the effect of water activity on the growth of moulds. International Journal of Food Microbiology, v.63, n.3, p.265-273, 2001.

ROSTAGNO, H.S.; ALBINO, L.F.T.; DONZELE, J.L.; GOMES, P.C.; OLIVEIRA, R.F.M.; LOPES, D.C.; FERREIRA, A.S.; BARRETO, S.L.T.; EUCLYDES, R.F. Tabelas Brasileiras para Aves e Suínos - Composição de Alimentos e Exigências Nutricionais. 3. ed. Visconde do Rio Branco, MG: Suprema, 2011, v.01, 252p.
SANTIN, J.A.; REIS, E.M.; MATSUMURA, A.T.S.; MORAES, M.G. Efeito do retardamento da colheita de milho na incidência de fungos patogênicos e de grãos ardidos. Ciência Rural, v.03, n.02, p.182-192, 2004.

SARAIVA, A.; DONZELE, J.L.; OLIVEIRA, R.F.M.; ABREU, M.L.T.; SILVA, F.C.O.; GUIMARAES, S.E.F.; KIM, S.W. Phosphorus requirements for 60- to 100-kg pigs selected for high lean deposition under different thermal environments. Journal of Animal Science, v.90, p.1499$1505,2012$.

SILVA, J.B.; POZZI, C.R.; MALLOZZI, M.A.B; ORTEGA, E.M.; CORRÊA, B. Mycoflora and occurrence of Aflatoxin B 1 and Fumonisin B 1 during storage of Brazilian sorghum. Journal of Agricultural and Food Chemistry, v.48, p.4352-4356, 2000.

SILVA, D.J.; QUEIROZ, A.C. Análises de alimentos: métodos químicos e biológicos. Viçosa: UFV, 2002. 235p.

SONE, J. Mold growth in maize storage as affected by compound factors: different levels of maize weevils, broken corn and foreign materials, and moisture contents. Journal of AsiaPacific Entomology, v.4, n.1, p.17-21, 2001.

TANAKA, M.A.S.; MAEDA, J.A.; PIAZAS, I.H.A.Z. Microflora fúngica de sementes de milho em ambientes de armazenamento. Scientia Agricola, v.58, n.3, p.501-508, 2001.

TRINDADE NETO, M.A.; BERTO, D.A.; ALBUQUERQUE, R.; SCHAMMASS, E.A.; MIGUEL, W.C. Níveis de proteína em dietas de suínos em fase de crescimento e terminação.

Brazilian Journal of Veterinary Research and Animal Science, v.46, n.6, p.474-483, 2009.

UNDERWOOD, E.J.; SUTTLE, N.F. The mineral nutrition of livestock. 3.ed. New York: CABI Publishing, 1999. 598p.

Recebido para publicação em 28/12/2014 e aprovado em 30/07/2015. 